\title{
Selected factors determining the choice of cosmetic masks by cosmetologists
}

\author{
Wybrane czynniki decydujace o wyborze \\ masek kosmetycznych przez kosmetologóu
}

\begin{abstract}
A very important issue in the practice of cosmetologists is the selection of an appropriate cosmetic mask at the end of each care treatment. Due to their effects, cosmetic masks can contain various active substances in different concentrations that are tailored to the needs of a given skin type.

The aim of the study was to investigate what are the guidelines of cosmetologists while choosing cosmetic masks in a beauty salon and home care.
\end{abstract}

Keywords: skin, mask, cosmetic masks, active substances, problematic skin

\section{STRESZCZENIE}

W praktyce kosmetologów, bardzo istotnym etapem końcowym każdego zabiegu pielęgnacyjnego jest nałożenie odpowiedniej maski kosmetycznej. Ze względu na swoje właściwości maski kosmetyczne mogą zawierać wiele substancji aktywnych, o różnych stężeniach, odpowiednio dopasowanych do potrzeb danego rodzaju skóry.

Celem pracy było zbadanie czym kierują się kosmetolodzy podczas wyboru masek kosmetycznych do zastosowań w gabinecie kosmetologicznym oraz w pielęgnacji domowej.

Słowa kluczowe: skóra, maska, maski kosmetyczne, substancje aktywne, skóra problematyczna

\section{INTRODUCTION}

Proper daily skin care is the basis for maintaining a youthful appearance. Regardless of the type, the skin requires the selection of appropriate cosmetic preparations and treatments.

Cosmetic masks are one of the most frequently used forms of care in beauty salons and SPA centres. This is a wide group of products that are used as an addition to treatments. Cosmetic masks contain active ingredients that are tailored to the needs of customers [1-5].

Cosmetic concerns compete with each other to create newer, more innovative cosmetics which, in line with the trends, must be as natural as possible.

\section{TYPES OF MASKS}

Among the cosmetic masks available on the market, we can distinguish masks for professional use and masks intended for home care [1, 2, 4, 6].
Cosmetic masks can be divided into moisturizing, whitening, cleansing, astringent, loosening, cooling, exfoliating, and special ones.

The second division is based on the form of the mask: cream, sheet, clay, powder, foam, gel and herbal [2, 4, 7-10].

- Moisturizing masks strongly moisturize the skin. They are intended for dry, gray, and hypoxic skin. They may contain hyaluronic acid, vitamins, allantoin, oils, and plant extracts. A thicker layer of the mask should be applied to cleansed skin and left to absorb or wash off the residue. They are most often found in gel or cream form $[1,11]$.

- Whitening masks usually contain AHA (alpha-hydroxy acids), BHA (beta-hydroxy acids), retinol, or vitamin C. These ingredients influence melanogenesis, tyrosinase, and processes that affect melanin production and skin color. They also exfoliate and lighten the skin. Frequently, there are mixtures of ingredients that complement each 
other and enhance their effect. It is strongly remembered to use sun protection after using such masks [11, 12].

- Cleansing masks have a light consistency, they cleanse the skin of impurities and dead epidermis. They also help to even out the skin tone, make it brighter and smoother. They include peeling acids or enzymes, so they should not be used too often, because they can dry out the skin and irritate it. Cleansing masks are used for oily and combination skin [1].

- Astringent masks are designed for problematic and acne-prone skin, they are also used after cleansing. They may contain: zinc oxide, kaolin, chalk, diatomaceous earth, magnesium carbonate, and aluminium acetate, but they are devoid of emulsion and greasy ingredients. These masks are usually applied with a brush and allowed to dry. They are washed with cool water [1, 13, 14].

- The softening masks are recommended especially for oily and contaminated skin. Due to the occlusion phenomenon, the skin is more moisturized, smoothed, and better absorbs active substances. The mask is usually put on before manual facial cleansing to soften the skin. Typical examples of softening masks are self-heating masks made of sea mud, paraffin masks, and poultices, like herbal masks [1].

- Cooling masks can be used for practically all skin types, especially for skin with dilated capillaries. They often contain menthol and other active ingredients causing a feeling of cooling and soothing irritation, as well as soothing substances [15].

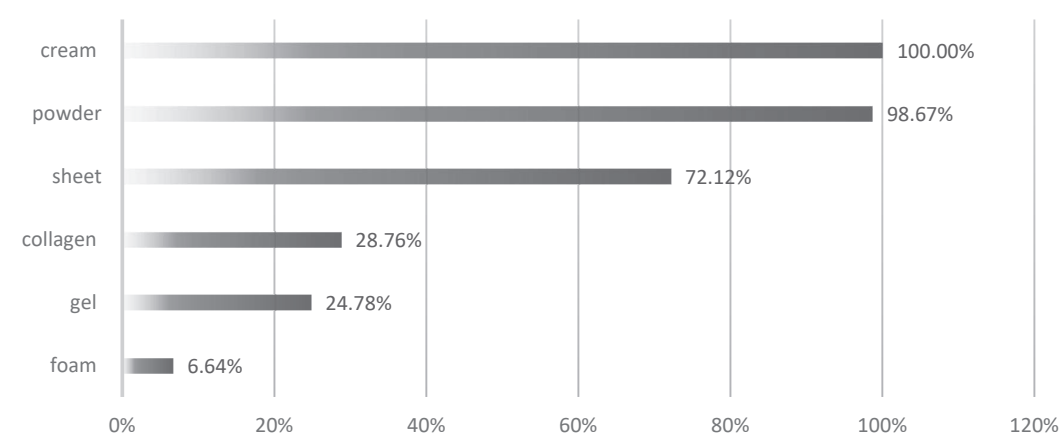

Fig. 1 Types of masks used in beauty salons. Source: Own study

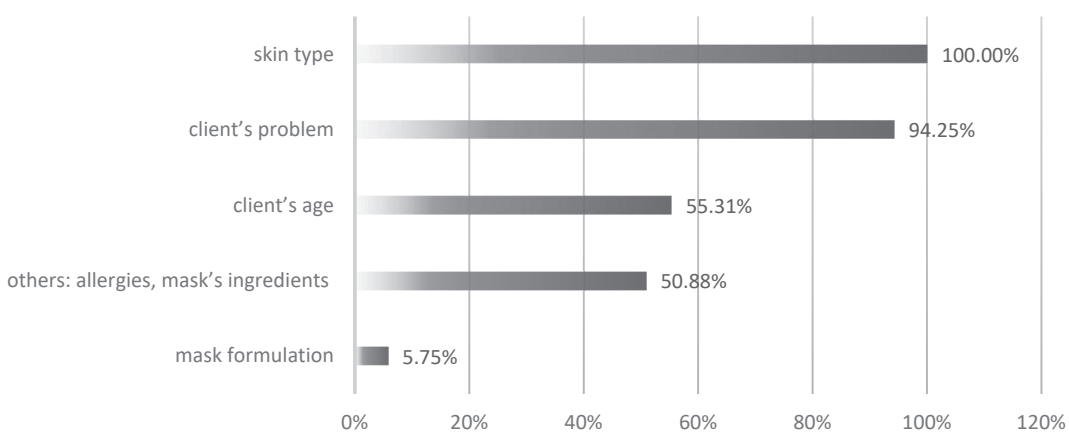

Fig. 2 Preferences of cosmetologists regarding the choice of types of cosmetic masks. Source: Own study
- Exfoliating masks are designed to remove calloused epidermis and impurities. This type of mask may contain acids, AHA, which are responsible for dissolving the superficial layers of the epidermis, as well as particles of plant or of synthetic origin, which mechanically remove dead epidermis. This type of mask includes peel-off masks. The frequency of using this type of mask depends on the type of skin, it should be remembered that excessive and too frequent use may lead to skin dryness [13].

- Special masks which include lifting masks. They give a short-term effect: they tighten the skin, smooth out wrinkles, and improve the contour of the face. These masks are also called the „Cinderella effect” or banquet masks. They contain alginates, aloe, silicone, argireline, as well as substances that tighten the skin for a specific period of time. These masks also use synthetic or organic substances that cause the refraction of light, making the skin optically radiant and illuminated. The formula of the masks may vary $[1,13]$.

\section{AIM OF THE WORK}

The main aim of the work was to investigate what are the main guidelines of cosmetologists when choosing cosmetic masks in a beauty salon.

\section{MATERIAL AND METHODS}

Anonymous surveys of 226 cosmetologists were conducted in Małopolska. All respondents were professionally active.

The survey consisted of 39 questions. It was conducted over a period of three months - from April to June 2021, on the Internet and the paper form of the survey. In total, 226 completed questionnaires were received: 170 in paper form and 56 in electronic form.

The analysis of the results and detailed variants of the answers were described and elaborated in Excel and then presented in column charts.

\section{RESULTS}

All cosmetologists chose algae masks for beauty treatments.

Clay and gel masks were also often used, while sheet masks were the least frequently chosen by cosmetologists only $15 \%$ of respondents decided to use them (Fig. 1).

Cosmetologists most often chose powder masks (93\%), cream masks (92.6\%), and sheet masks (87.6\%) for care treatments. Paraffin masks were the least frequently chosen, only by $3 \%$ (Fig. 2). 
All surveyed cosmetologists most often used moisturizing masks (100\%). Masks with cooling, softening, warming, special (e.g. botox-like), astringent, exfoliating, and whitening properties were chosen by the majority of respondents (over $69.91 \%$ ). On the other hand, the least studied cosmetologists (42.04\%) used medicinal masks (Fig. 3).

When choosing a mask, cosmetologists were guided by the type of skin of the clients (100\%), skin problems (94\%), age $(55.8 \%)$, allergies $(50.9 \%)$, and the form of the mask (5.8\%) (Fig. 4).

All the surveyed cosmetologists used cream masks in case of home care. Most of them used powder and sheet masks, and the least frequently used were foam masks (6\%) (Fig. 5).

\section{DISCUSSION}

After analyzing the results of the survey, it turned out that cosmetologists most often indicated cream masks (226 - 100\%), powder masks (223 - 98.7\%), and sheet masks (163 - 72.1\%) as their home skin care. On the other hand, in beauty salons, taking into account the criterion of influence on the skin, moisturizing masks were the most frequently used by cosmetologists.

Research conducted in Brazil at the University of Sao Paulo showed that peeloff masks moisturize the skin better than oil-in-water (o / w) emulsions. Measurements were conducted by a CM 825 PC corneometer, a TW 210 tevameter, and a SEM 575 cutometer. The test lasted three hours and was carried out in a temperature-controlled room. At the same time, the measurements showed that both the peel-off mask and the emulsion had no significant effect on the elasticity or firmness of the skin [16].

Four different recipes were created: two masks (one with fermented soybean extract, the other without) and two emulsions (one with soybean extract, the other without). Each preparation was applied in fifteen places. The slides were kept on the face for 20 minutes, and on the forearms throughout the entire study period.

Cosmetic masks, thanks to the creation of occlusions on the skin, partially limit transepidermal water loss (TEWL), which supports the process of moisturizing the stratum corneum. This contributes to the smoothing of the skin and its better appearance.

Source: Own study

Source: Own study

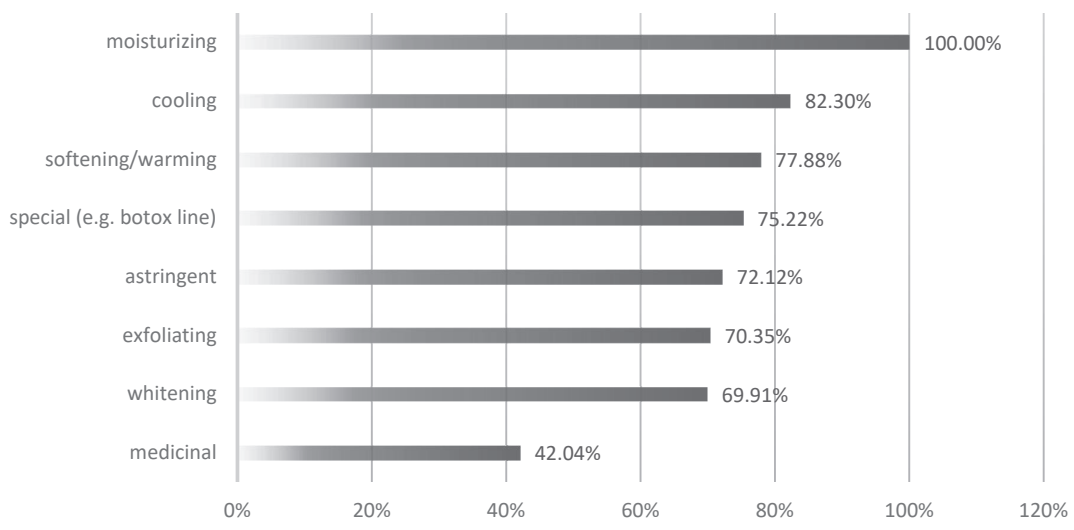

Fig. 3 Masks the most often used by cosmetologists in terms of their effect on the skin.

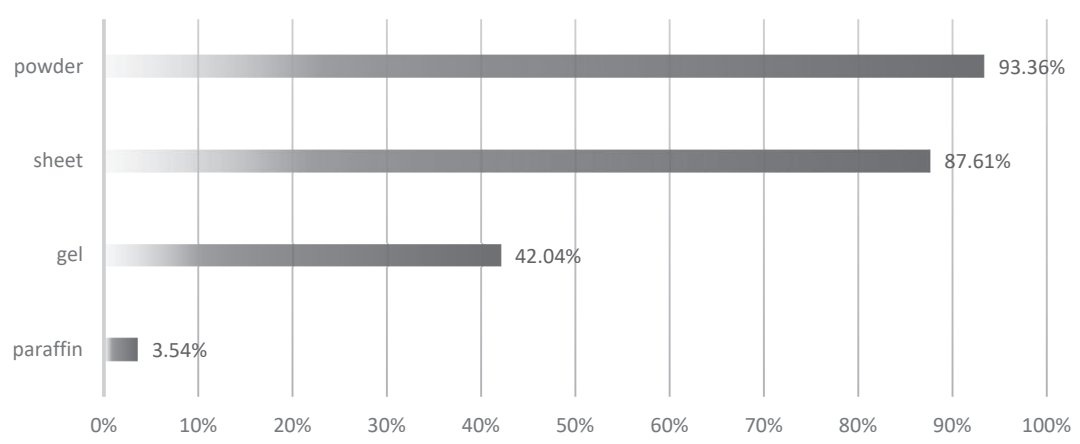

Fig. 4 Criteria for choosing a mask for a client by a cosmetologist.

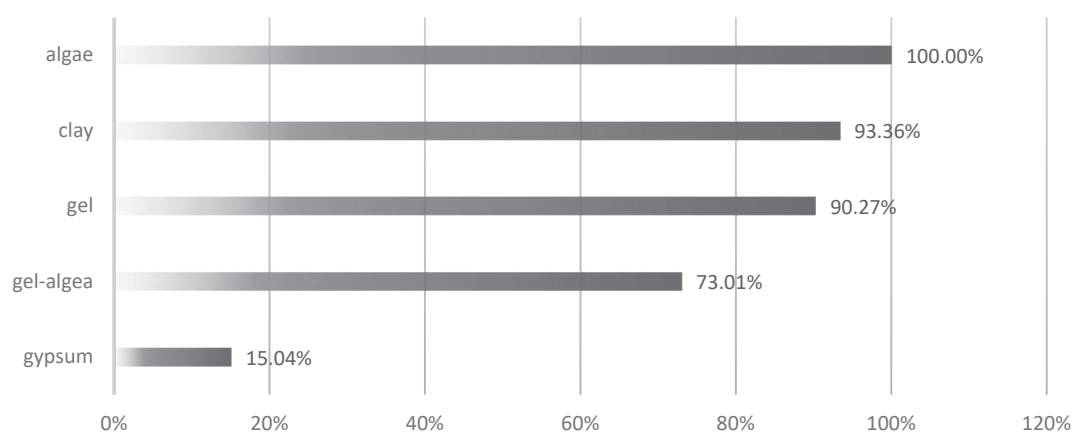

Fig. 5 Cosmetic masks used by cosmetologists for home care.

Research on cosmetic masks and their properties should be carried out on a larger scale, taking into account more types of masks and skin types.

\section{CONCLUSIONS}

Cosmetologists declare that they most often use moisturizing masks to care for their clients' skin in beauty salons. When choosing, they take into account such factors as skin type, skin problems, and age. When it comes to the form of the mask, they choose powder and cream masks. When purchasing a mask for personal use, they are guided by the composition of the product and cosmetic certificates. 


\section{REFERENCES / LITERATURA}

1. Możdżeń K, Barabasz-Krasny B, Szymacha K, Oliwa J. Rośliny w maskach kosmetycznych. Pol J Cosmetol. 2016;19(4):372-379.

2. Nilforoushzadeh MA, Amirkhani MA, Zarrintaj P, et al. Skin care and rejuvenation by cosmeceutical facial mask. J Cosmet Dermatol. 2018;17(5):693-702. https://doi.org/10.1111/jocd.12730

3. Dylewska-Grzelakowska J. Kosmetyka stosowana. Warszawa: WSziP; 2005:71-74.

4. Jaroszewska B. Kosmetologia. Warszawa: Atenum; 2014:352.

5. Nilforoushzadeh MA, Amirkhani MA, Zarrintaj P, et al. Skin care and rejuvenation by cosmeceutical facial mask. J Cosmet Dermatol. 2018;17(5):693-702.

6. Marzec A. Chemia kosmetyczna. Surowce, pótprodukty, prepararyka wyrobów. Toruń: TNOIK Dom Organizatora; 2005:360.

7. Pan-On S, Rujivipat S, Ounaroon A, Tiyaboonchai W. Development and characterization of clay facial mask containing turmeric extract solid dispersion. Drug Dev Ind Pharm. 2018;44(4):590-597. https://doi.org/10.1080/03639045.2017.1405434

8. Bacler-Żbikowska B, Maruszewska E. Wykorzystanie brunatnic Phaeophyta w kosmetyce. Pol J Cosmetol. 2018;21(3):199-205.
9. Meier L, Stange R, Michalsen A, Uehleke B. Clay jojoba oil facial mask for lesioned skin and mild acne-results of a prospective, observational pilot study. Forsch Komplementmed. 2012;19(2):75-79. https://doi.org/10.1159/000338076

10. Perugini P, Bleve M, Redondi R, et al. In vivo evaluation of the effectiveness of biocellulose facial masks as active delivery systems to skin. J Cosmet Dermatol. 2020;19(3):725-735.

11. Noszczyk M. Medycyna piękności. Warszawa: Wyd. PZWL; 2016.

12. Noszczyk M. Kosmetologia pieleggnacyjna i lekarska. Warszawa: Wyd. PZWL; 2010:221-222.

13. Kołodziejczak A. Kosmetologia Tom 1. Warszawa: Wyd. PZWL; 2019: 378-382.

14. Kamińska A, Jabłońska K, Drobnik A. Praktyczna kosmetologia krok po kroku. Kosmetologia twarzy. Warszawa: Wyd. PZWL; 2014.

15. Rapacka-Gackowska A, Matławska I. Glony jako źródło surowców kosmetycznych. Pol J Cosmetol. 2013;16(3):205-210.

16. Velasco MV, Vieira RP, Fernandes AR, et al. Short-term clinical of peel-off facial mask moisturizers. Int J Cosmet Sci. 2014;36(4):355-360. https://doi.org/10.1111/ics.12133

otrzymano/received: 05.10.2021 | poprawiono/ corrected: 17.10.2021 | zaakceptowano/accepted: 04.11.2021 